\title{
EFFECT OF INITIAL STRENGTH OF HONEY BEE COLONIES (Apis mellifera) SUPERED IN DIFFERENT WAYS ON MAXIMIZING HONEY PRODUCTION IN NEPAL
}

\author{
Khem Raj Neupane ${ }^{1}$, Jerzy Woyke ${ }^{2}$, Jerzy Wilde \\ 'Department of Entomology, Tribhuvan University, Institute of Agriculture \\ and Animal Sciences (IAAS), Rampur, Chitwan, Nepal krneupane@hotmail.com \\ ${ }^{2}$ Apiculture Division, University of Life Science, 166 Nowoursynowska, \\ 02-787 Warsaw, Poland jerzy woyke@sggw.pl. \\ ${ }^{3}$ Apiculture Division, University of Warmia and Mazury, \\ 10-710 Olsztyn, Poland jerzy.wilde@uwm.edu.pl
}

Received 16 May 2012; accepted 17 September 2012

\section{$\mathrm{S} \mathrm{u} \mathrm{m} \mathrm{m} \mathrm{a} \mathrm{r} \mathrm{y}$}

A study was carried out to investigate the effect of the original strengths of honey bee colonies supered in different ways, on the production of honey by Apis mellifera bees in the Terai region of Nepal. Bee colonies of three different original strengths, in which the bees covered 5, 10 and 20 combs, were supered in three different methods. The results showed that honey production was highly correlated to the number of worker brood cells in the colonies $(r=0.96$, $\mathrm{p}=0.003$ ). Colonies of $5 \mathrm{comb}$ initial strength (CIS), as farmers' practices in Nepal, produced the lowest amount of honey (30.1 kg per annum). Bees in colonies of 10 CIS with a deep super, produced twice as much honey $(62.2 \mathrm{~kg})$, and colonies of 20 CIS with deep supers produced even significantly more honey $(74.5 \mathrm{~kg})$. However, the relationship between the financial values of the produced honey to the cost of its production was the highest $-1.52: 1$ for colonies of 10 CIS with a deep super. Therefore, this bee colony management is recommended to the beekeepers in the Terai region and lower hills of Nepal. This finding has global application.

Keywords: initial strength of bee colonies, supering, honey production, Nepal.

\section{INRODUCTION}

The domesticated native honey bee of Nepal is Apis cerana. Traditionally, it is kept in horizontal log hives and wall hives. About 1977, the modern movable frame hives were introduced to Nepal (Kafle, 1992; Bhusal and Thapa, 2006). The honey production from A. cerana is low (about $4 \mathrm{~kg}$ per colony) compared to the European bee A. mellifera. Between 1993 and 1995 the honey bee A. mellifera, was introduced into Nepal, from a temperate region of Europe (Bhusal and Thapa, 2006). In Nepal A. mellifera was considered exotic. The climatic conditions and the nectar resources in the Terai region and the lower hills of Nepal, where the A. mellifera was introduced and is kept, differ from those where from this native bee originated
(Pratap, 1997; Shrestha and Shrestha, 1998). A suitable management practice which would provide the highest honey production and benefits to Nepalese beekeepers needed to be developed.

It is generally accepted that honey production depends on the population of the bee colonies (Farrar, 1937; Harbo, 1986; Kumar et al., 1995). In turn, the bee colony strength depends on the amount of brood produced (Szabo, 1982; Szabo and Lefkovitch, 1989; Bhusal et al., 2011). According to Woyke (1984), however, high variation exists between the amount of brood and honey production $(\mathrm{r}=0.20$ to 0.85 ), and between the strength of the colonies and the honey yield $(\mathrm{r}=0.38$ to $0.70)$. 
In the Terai region of Nepal the climate is warm throughout the year. The warm climate enables what the Nepalese consider to be the exotic bee A. mellifera to be active throughout the year without reproductive diapauses. Such activity does not allow the European management practices of $A$. mellifera to be duplicated in a country like Nepal. The development of location-specific management practices for successful beekeeping with A. mellifera proved necessary in Nepal.

The purpose of our investigation was to find out how the initial strength of the colonies managed in different ways affects the honey production in Nepal, and which of the management methods results in the highest benefits for the beekeepers.

\section{MATERIALS AND METHODS}

The experiment was conducted in the southern part of Nepal in the Terai region and the mid hills (Fig. 1). The apiary was migrated to three sites. The first site, Tulsipur, was in the Dang district in the valley of the mid hills of the western region between $27^{\circ} 03^{\prime}$ and $28^{\circ} 29^{\prime} \mathrm{N}$, and between $82^{\circ} 02^{\prime}$ and $82^{\circ} 51^{\prime} \mathrm{E}$, with an altitude range from 213 to $2057 \mathrm{~m}$. The second site was in Nawalpur of the Nawalparasi district between $27^{\circ} 12^{\prime}$ and $27^{\circ} 47^{\prime} \mathrm{N}$, and between $83^{\circ} 36^{\prime}$ and $84^{\circ} 35^{\prime} \mathrm{E}$, alt. 100 to $1936 \mathrm{~m}$. The third site was at Dibya Nagar and Rampur in the Chitwan district between $27^{\circ} 21^{\prime}$ and $27^{\circ} 52^{\prime} \mathrm{N}$, and between $83^{\circ} 21^{\prime}$ and $84^{\circ} 48^{\prime} \mathrm{E}$, alt. 141 to $1943 \mathrm{~m}$.

The experiment was conducted repeatedly for 3 years (2003/2004, $2004 / 2005$ and $2005 / 2006$ ) starting at the beginning of nectar flow in August and ending in May of each year.

Two factors influencing the productivity of bee colonies were investigated: $1 /$ initial colony strength, in which the bees covered three different numbers of combs: 5, 10 and 20, and 2/ three methods of supering: no super, one shallow, or one deep super. Unfortunately, all 9 combinations (3 initial strengths x 3 supering methods) could not be investigated because the colonies of 5 comb initial strength (CIS) were to weak to receive shallow or deep super, and the colonies of 20 (CIS) were too strong to not receive a super. Thus, instead of 9 combinations, 6 treatments were investigated. Each treatment was investigated (repeated) in 6 colonies. Thus, each of the three characteristics (amount of brood, number of foragers and honey production) was investigated yearly in 36 bee colonies ( 6 treatments $\times 6$ colonies). The investigation was repeated during the

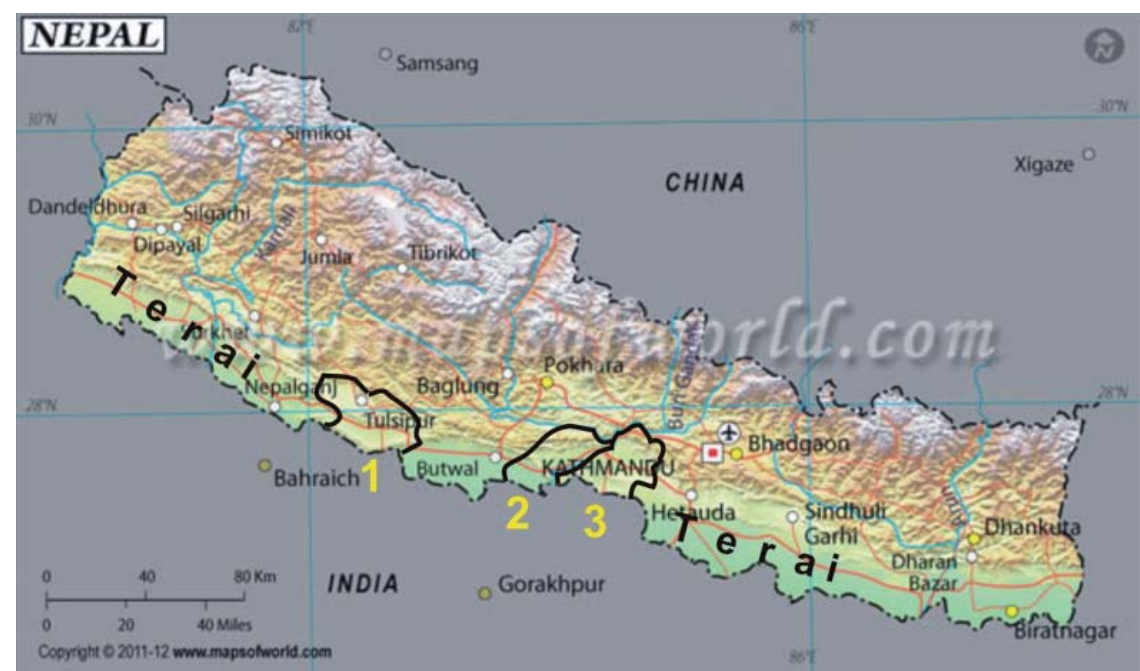

Fig. 1. Nepal districts in which the investigation was conducted: 1 - Dang, 2 - Navalparasi, 3 - Chitwan. 
3 year periods. Each year, new colonies were created. Hence, the investigation was conducted in 108 colonies (36 x 3). Data were recorded each year for three seasons (autumn, winter, and spring). Altogether, 324 records $(108 \times 3)$ were obtained for each characteristic.

The colonies for the experiment were prepared in 10 frame Langstroth hives at the beginning of the honey flow in August.

The six experimental treatments (Tr.) were as follows:

Tr. 1 - (5 CIS $)$. The bees covered 5 combs out of which 3 contained worker brood. The weight of the bees was $1.5 \mathrm{~kg}$. Each colony was given new frames with wax foundation.

Tr. 2 - (10 CIS $)$. The bees covered 10 combs out of which 6 contained brood. The weight of the bees was $3.0 \mathrm{~kg}$ per colony.

Tr. 3 - (10 CIS with shallow super). The bees covered 10 combs out of which 6 had brood. The weight of the bees was $3.0 \mathrm{~kg}$. One shallow super containing 10 built combs was added to each colony. It was separated from the nest by a queen excluder.

Tr. 4 - (10 CIS with deep super). The bees covered 10 combs out of which 6 contained worker brood. The weight of bees was $3 \mathrm{~kg}$. One deep super with 10 built combs was added to each colony. It was separated from the nest by a queen excluder.

Tr. 5 - (20 CIS in a double brood chamber with a shallow super). The bees covered 20 combs out of which 12 contained worker brood. The weight of the bees was $6 \mathrm{~kg}$.

One shallow super with 10 built combs was added. It was separated from the nest by a queen excluder. The two brood chambers used for brood production (one upper and one lower) were replaced every 14 days.

Tr. 6 - (20 CIS in a double brood chamber with a deep super). The bees covered 20 combs out of which 12 contained brood. The weight of the bees was $6.0 \mathrm{~kg}$. One deep super with 10 built frames was placed over the queen excluder. The two bottom brood chambers were replaced every 14 days.

The colonies were migrated each year to Tulsipur of Dang during the beginning of September on mustard (Brassica spp) crop. Then, they were migrated to Nawalpur of Nawalparasi at the end of November, again over mustard crop (Brassica spp). After this, the colonies were migrated to Dibya Nagar and Rampur of the Chitwan district during December, over buckwheat, (Fagopyrum esculentum), rudhilo (Pogostemon glaber) and litchi (Litchi chinensis syn. Nephelium litchi) crops.

The worker brood area (eggs, larvae or pupae) on the combs was measured at 21-day intervals from October to March. A conversion into the number of brood cells was made with the help of a brood measuring table developed by Woyke (1981a).

The numbers of workers flying out of the hive were counted per 5 minutes at the hive entrance at 21 day intervals. Counting was done at the peak foraging time of the day and peak flowering period during the autumn, winter, and spring seasons.

The honey yield was recorded separately for each autumn, winter, and spring.

The honey production costs for each experimental colony were calculated from the existing price of materials, feedings, transportation, and labor, and summed up separately. Similarly, the income from each colony was calculated from the existing wholesale price of honey. The net profit was calculated by subtracting the production costs from the honey income. A cost-benefit analysis was done for each supering method, and the most cost-effective supering method for honey production was then recommended.

For statistical analysis, one-factor, or two-factor ANOVA was applied, and Duncan's multiple test was used to detect significant differences between the means. Correlation coefficient between different characteristics was also calculated. 


\section{RESULTS}

Brood amount in colonies of different initial strength supered differently

Two-factor ANOVA showed that the numbers of brood cells were highly significantly affected by the three seasons; $\mathrm{F}_{2,323}=37.49, \mathrm{p}=0.000$, as well as by the six treatments of the colonies; $\mathrm{F}_{5,323}=24.07$, $\mathrm{p}=0.000$. Highly significant interaction between the two factors occurred; $\mathrm{F}_{10,323}=2.39, \mathrm{p}=0.01$. This indicates that with the pass of the seasons, the brood quantity did not change evenly.

The colonies were prepared in August. Table 1 shows that significant changes occurred during three seasons. In the colonies of 5 CIS, the number of brood cells was low in autumn (8.3 thousand). It decreased insignificantly in winter but it increased as much as 2.1 times in the spring (17.4 thousand). The increase was so high that no significant differences were found between the number of brood cells in the colonies of 5 CIS and the spring numbers of brood in the stronger colonies of 10 CIS supered in three ways and even in colonies of $20 \mathrm{CIS}$ with a shallow super.

In colonies of $10 \mathrm{CIS}$, the seasonal mean number of brood cells for colonies supered in 3 ways was significantly the lowest in winter (12.4 thousand), and significantly the highest in the spring (18.2 thousand). The spring increase in these colonies, though, was only 1.3 times higher than in autumn.

In colonies of $20 \mathrm{CIS}$, the seasonal mean number of brood cells for colonies supered in 2 ways was significantly the lowest in winter. No significant difference was found between the number of brood cells in autumn and in spring.

The changes in the amount of brood production over the three seasons were very different in colonies of different CIS. Colonies of 5 CIS increased their brood production till spring 2.1 times. Colonies of 10 CIS increased their brood production 1.3 times, and the strongest colonies of 20 CIS did not increase brood production in the spring. Thus, in the spring, the amount of brood in the weakest colonies approached that of the stronger colonies.

Taking into account the mean number of brood cells in the three seasons (autumn, winter, and spring) in colonies of the three groups (of 5, 10, and 20 CIS), the bees produced brood at a rate of $(1.0: 0.9: 2.1)$ : $(1.7: 1.5: 2.2):(2.4: 2.1: 2.5)$ in comparison to the 8.3 thousand brood cells in colonies of 5 CIS in autumn. The amount of brood in colonies of the three different strengths differed a great deal at the beginning of the season in autumn (1.0:1.7:2.4, maximal difference 1.4$)$ and was more similar at the end of the season in spring $(2.1: 2.2: 2.5$, maximal difference $0.4)$.

The seasonal overall mean for the treatment, within each of the three CIS groups showed the lowest number of brood cells (10.9 thousand) in the colonies of 5 CIS (Tab. 1). In colonies of 10 CIS, significantly 1.2 times more brood was found in hives with a deep super (16.3 thousand) than in hives without a super (13.6 thousand). In colonies of 20 CIS, no significant difference was found between the numbers of brood cells in hives with a shallow or deep super. Thus, the supering method was significantly effective in brood production in colonies of 10 CIS.

Taking into account all six treatments of the three groups of colonies (of 5, 10 and 20 CIS), the seasonal overall mean number of brood cells was at a rate of $1:(1.2: 1.4: 1.5):(1.8: 1.8)$, in comparison to the 10.9 thousand brood cells in colonies of 5 CIS without super.

The initial colony strength of 5, 10, and 20 combs (ratio $1: 2: 4$ ) resulted in an overall mean number of brood cells at a rate of $1.0: 1.4: 1.8$, in comparison to the 10.9 thousand cells in colonies of 5 CIS. Thus, in proportion to the strength of the colonies, the lowest increase of the brood amount occurred in the strongest colonies.

Number of foragers flying from colonies of different initial strengths supered differently

The two-factor ANOVA showed that the number of outgoing foragers was highly significantly affected by the three seasons; 
Table 1 .

Number of worker brood cells (thousands, per observation) in colonies of different-initial-strength, supered in three methods, in the Terai region of Nepal (2003-2006). Each mean takes into account 18 records ( 6 colonies x 3 years), and each overall mean, - 54 records for 3 years $(18 \times 3)$

\begin{tabular}{|c|c|c|c|c|c|}
\hline $\begin{array}{l}\text { Colony } \\
\text { strength }\end{array}$ & Season & $\begin{array}{c}\text { Without a super } \\
\text { Mean } \pm \text { se }\end{array}$ & $\begin{array}{l}\text { Shallow super } \\
\text { Mean } \pm \text { se }\end{array}$ & $\begin{array}{l}\text { Deep super } \\
\text { Mean } \pm \text { se }\end{array}$ & Seasonal mean \\
\hline \multirow{4}{*}{5 combs } & Autumn & $8.3 \pm 0.6 \mathrm{i}^{*}$ & - & - & $8.3 \mathrm{~B} \&$ \\
\hline & Winter & $7.1 \pm 1.5 i$ & - & - & $7.1 \mathrm{~B}$ \\
\hline & Spring & $17.4 \pm 2.8$ cde & - & - & $17.4 \mathrm{~A}$ \\
\hline & Overall mean & $10.9 \pm 0.7 \mathrm{~d} \#$ & & & 10.9 \\
\hline \multirow{4}{*}{10 combs } & Autumn & $13.2 \pm 1.4 \mathrm{fg}$ & $14.1 \pm 9.0 \mathrm{~g}$ & $15.0 \pm 1.4 \mathrm{efg}$ & 14.1B \\
\hline & Winter & $10.0 \pm 2.0 \mathrm{hi}$ & $12.5 \pm 0.8 \mathrm{gh}$ & $14.7 \pm 4.4 \mathrm{efg}$ & $12.4 \mathrm{C}$ \\
\hline & Spring & $17.6 \pm 2.6$ bcde & $17.7 \pm 2.1 \mathrm{bcde}$ & $19.2 \pm 1.2 \mathrm{abc}$ & $18.2 \mathrm{~A}$ \\
\hline & Overall mean & $13.6 \pm 0.7 \mathrm{c}$ & $14.8 \pm 0.7 \mathrm{bc}$ & $16.3 \pm 0.7 b$ & 14.9 \\
\hline \multirow{4}{*}{20 combs } & Autumn & - & $20.8 \pm 2.4 \mathrm{ab}$ & $20.2 \pm 3.7 \mathrm{abc}$ & $20.3 \mathrm{~A}$ \\
\hline & Winter & - & $18.3 \pm 4.2 \mathrm{bcd}$ & $16.0 \pm 2.2 \mathrm{def}$ & $17.1 \mathrm{~B}$ \\
\hline & Spring & - & $20.2 \pm 2.5 \mathrm{abc}$ & $21.6 \pm 2.08 a$ & $20.9 \mathrm{~A}$ \\
\hline & Overall mean & & $19.7 \pm 0.7 \mathrm{a}$ & $19.1 \pm 0.7 a$ & 19.4 \\
\hline \multirow{2}{*}{\multicolumn{2}{|c|}{ Overall seasonal mean }} & Autumn & Winter & Spring & \\
\hline & & $15.2 \pm 0.5 \mathrm{~B} @$ & $131 \pm 0.5 \mathrm{C}$ & $18.9 \pm 0.5 \mathrm{~A}$ & \\
\hline
\end{tabular}

* Different small letters after the means indicate a significant difference $(\mathrm{P}<0.05)$ between them; \# Different small bold letters indicate 6 overall seasonal means (three lines);

\& Different regular-print Capital letters indicate only 3 seasonal means of same-strength colonies;

@ Different Capital Bold letters indicate the overall seasonal means (last line).

Table 2 .

Number of out-flying foragers per 5 minutes in different-initial-strength colonies supered in three methods, in the Terai region of Nepal (2003-2006)

\begin{tabular}{|c|c|c|c|c|c|}
\hline $\begin{array}{l}\text { Colony } \\
\text { strength }\end{array}$ & Season & $\begin{array}{c}\text { Without } \\
\text { super } \\
\text { Mean } \pm \text { se }\end{array}$ & $\begin{array}{l}\text { Shallow } \\
\text { super } \\
\text { Mean } \pm \text { se }\end{array}$ & $\begin{array}{l}\text { Deep super } \\
\text { Mean } \pm \text { se }\end{array}$ & $\begin{array}{l}\text { Seasonal } \\
\text { mean }\end{array}$ \\
\hline \multirow{4}{*}{5 combs } & Autumn & $189 \pm 47 h^{*}$ & - & - & 189A\& \\
\hline & Winter & $232 \pm 31 \mathrm{gh}$ & - & - & $232 \mathrm{~A}$ \\
\hline & Spring & $201 \pm 10 \mathrm{~h}$ & - & & $201 \mathrm{~A}$ \\
\hline & Overall mean & $207 \mathrm{D} \#$ & & & 207 \\
\hline \multirow{4}{*}{10 combs } & Autumn & $286 \pm 64 \mathrm{fg}$ & $314 \pm 52 f$ & $465 \pm 76 c$ & $355 \mathrm{~A}$ \\
\hline & Winter & $352 \pm 61$ def & $388 \pm 50 \mathrm{de}$ & $416 \pm 78 \mathrm{~cd}$ & $386 \mathrm{~A}$ \\
\hline & Spring & $283 \pm 37 \mathrm{fg}$ & $310 \pm 33 f$ & $323 \pm 32$ ef & $305 \mathrm{~B}$ \\
\hline & Overall mean & $307 b^{\star \star} C$ & $337 \mathrm{bC}$ & $401 \mathrm{aB}$ & 349 \\
\hline \multirow{4}{*}{20 combs } & Autumn & - & $742 \pm 71 \mathrm{a}$ & $764 \pm 119 a$ & $753 \mathrm{~A}$ \\
\hline & Winter & - & $584 \pm 52 b$ & $645 \pm 83 b$ & $614 \mathrm{~B}$ \\
\hline & Spring & - & $397 \pm 47$ cde & $416 \pm 32 \mathrm{~cd}$ & $406 \mathrm{C}$ \\
\hline & $\begin{array}{l}\text { Overall } \\
\text { mean }\end{array}$ & & $574 \mathrm{aA}$ & $608 \mathrm{aA}$ & 591 \\
\hline
\end{tabular}

* Different small letters after the means indicate a significant difference $(\mathrm{P}<0.05)$ between them;

** Different small bold letters indicate overall seasonal means of the same initial-strength colonies supered differently (in one line);

\# Different Capital Bold letters indicate 6 overall seasonal means of all different initial strength colonies supered differently (three different lines);

$\&$ Different Capital regular-print letters indicate only 3 seasonal means of same-strength colonies. 
$\mathrm{F}_{2,323}=47.99, \mathrm{p}=0.000$, as well as by the six treatments; $F_{5,323}=107.75, p=0.000$. Also, the interaction between the treatment and the season was highly significant; $\mathrm{F}_{10,323}=10.91, \mathrm{p}=0.000$.

Table 2 shows that the seasonal mean number of outgoing foragers differed within same-initial-strength colonies supered in three methods. In colonies of 5 CIS, no significant differences were found between the mean numbers of foragers flying out during different seasons. In colonies of $10 \mathrm{CIS}$, the seasonal mean number of bees flying out during a 5 min period was significantly the lowest at the end of the nectar flow, in spring (305). It was 1.3 times lower than in winter (386). In colonies of 20 CIS, the seasonal mean number of out-flying foragers was significantly the lowest at the end of the nectar flow, in the spring (406). It was 1.9 times lower than in the beginning of the flow in autumn (753). Thus, the number of foragers flying out of the weaker colonies of 5 and 10 CIS increased in the next nectar flow in winter. However, in the strongest colonies of 20 CIS, the number of foragers decreased in the next two seasons, in winter and spring.

The different treatment of colonies of 10 CIS resulted in an overall seasonal mean number of foragers flying at a rate of $1.0: 1.1: 1.3$ from colonies without super, or with shallow or deep super respectively, in comparison to the 307 foragers from hives without super (Tab. 2).

In colonies of $20 \mathrm{CIS}$, the mean number of flying bees was not found to differ between colonies with a shallow and deep super.

Taking into account all six treatments of the colonies of the three groups of 5,10 , and $20 \mathrm{CIS}$, the seasonal overall mean number of foragers was at a rate of $1:(1.5: 1.6: 1.9):(2.8: 2.9)$, in comparison to the 207 bees flying out during a $5 \mathrm{~min}$ period, from the colonies of 5 CIS.

Concerning the initial strength of colonies of 5, 10 and $20 \mathrm{CIS}$, (strength rate $1: 2: 4$ ), the overall seasonal mean number of foragers flying from those colonies was at a rate of $1: 1.7: 2.9$, in comparison to the 207 foragers flying out during a $5 \mathrm{~min}$ period from colonies of 5 CIS. Thus, the lowest ratio of foragers flew out from the strongest colonies of 20 CIS.

Honey production by colonies of different initial strength supered differently

The two-factor ANOVA showed that the seasonal mean honey production per colony was highly significantly affected by the season; $\mathrm{F}_{2,323}=89.73, \mathrm{p}=0.000$, as well as the six treatments; $\mathrm{F}_{5,323}=57.20$, $\mathrm{p}=0.000$. However, interaction between the two factors was not found to differ significantly; $F_{10.323}=1.74, p=0.07$. The one-factor ANOVA showed that the six treatments highly significantly influenced the total annual honey production; $\mathrm{F}_{5,107}=61.57, \mathrm{p}=0.000$.

Seasonal differences of honey production within colonies of the same initial strength occurred (Tab. 3). Colonies of 5 CIS produced significantly the lowest yield at the beginning of the nectar flow, in autumn $(4.3 \mathrm{~kg})$. However, they produced as much as 3.3 times more honey at the end of the flow, in the spring $(14.0 \mathrm{~kg})$ than in autumn. The spring increase in the weakest colonies was so high, that it did not differ significantly from the spring honey production by the stronger colonies of 10 CIS without super. Thus, in spring, the colonies of 5 CIS reached the production of colonies of 10 CIS without super.

Colonies of 10 CIS supered in the three ways, produced on average, significantly the lowest yield at the beginning of nectar flow in autumn $(10.2 \mathrm{~kg})$ and a significantly higher yield in winter and spring. However, the production was only 1.8 times higher at the end of the flow in spring $(18.7 \mathrm{~kg})$ than in autumn.

Colonies of 20 CIS supered differently, produced on average, significantly the lowest yield in autumn $(16.7 \mathrm{~kg})$. They produced 1.8 times more in winter, but only 1.5 times more in spring.

Thus, the weaker colonies of 5 and 10 CIS produced the highest honey yield at the end of nectar flow in the spring, while the strongest colonies of 20 CIS produced the highest honey yield in the winter. 
Taking into account the seasonal mean amount of honey produced during the three seasons (autumn, winter, and spring) by colonies of the three original strengths of 5,10 and 20 CIS, the yield was at a rate of $(1.0: 2.7: 3.3):(2.4: 4.4: 4.4)$ $:(3.9: 7.0: 5.7)$, in comparison to the $4.3 \mathrm{~kg}$ of honey collected in autumn from colonies of 5 CIS. Thus, the autumn rate in colonies of the three strengths was at a rate of $1: 2.4: 3.9$, while the spring rate was $3.3: 4.4: 5.7=1: 1.3: 1.7$. These figures show that the results of the seasonal honey yield by colonies of different CIS rates became more similar at the end of the flow in spring.

The treatments significantly influenced the total annual mean production of honey by colonies of the same initial strength (Tab. 3). Colonies of 5 CIS which had not been supered produced the lowest total annual honey yield $(30.1 \mathrm{~kg})$. However, it was not found to differ significantly from the production by colonies of 10 CIS without a super. Thus, colonies of 5 CIS without a super produced a similar annual honey yield as those colonies of 10 CIS without a super.

However, within colonies of 10 CIS, significant differences in annual honey yield were found between colonies supered differently. While colonies without a super produced $34.1 \mathrm{~kg}$ of honey, those with a shallow super produced 1.4 times more $(47.5 \mathrm{~kg})$, and those with a deep super 1.8 time more $(62.2 \mathrm{~kg})$. Thus, supering the colonies of 10 CIS was very efficient. Those with a deep super produced almost twice as much honey as those without a super.

Colonies of 20 CIS supered with a shallow or deep super were not found to produce a significantly different annual amount of honey. Thus, the supering method was the most effective in colonies of 10 CIS.

Taking into account all six treatments of colonies from the three initial strength groups of 5, 10 and 20 CIS, the annual honey yield was at a rate of $1.0:(1.1: 1.6: 2.1)$ : $(2.3: 2.5)$ times as much as the $30.1 \mathrm{~kg}$ of honey produced by colonies of 5 CIS without a super.

Colonies of the three initial strengths of 5,10 and 20 combs (strength ratio $1: 2: 4$ ) produced a total annual mean of honey at a rate of $1: 1.6: 2.4$ times as much, as the $30.1 \mathrm{~kg}$ of honey extracted from colonies of 5 CIS. Thus, although the absolute amount of $71.6 \mathrm{~kg}$ of honey produced by colonies of 20 CIS was 2.4 times higher than that produced by colonies of 5 CIS, it was low in proportion to the initial 4-times-higher strength of the colonies of 20 CIS.

Correlation between brood amount, number of foragers and honey production by bee colonies

The correlation between the seasonal mean numbers of brood cells (Tab. 1) and the seasonal mean number of outgoing foragers (Tab. 2) was highly significant for the six treatment groups examined during the 3 years (6 groups x 3 years $=18)$; $\mathrm{r}=0.60, \mathrm{df}=17, \mathrm{p}=0.008$.

The correlation between the seasonal mean numbers of brood cells (Tab. 1) and the seasonal kilograms of honey produced by the colonies of the 6 treatment groups (Tab. 3) was significant; $r=0.58, d f=17$, $\mathrm{p}=0.012$. However, the correlation between the overall means of brood cells and the annual kilograms of honey produced by the colonies of the six treatment groups was higher and was highly significant; $r=0.96$, $\mathrm{df}=5, \mathrm{p}=0.003$. For the beekeeper, the annual honey production is more important.

The correlation between the seasonal mean numbers of outgoing foragers (Tab. 2) and the seasonal kilograms of honey (Tab. 3) produced by the colonies of the 6 treatment groups was significant; $\mathrm{r}=0.54, \mathrm{df}=17, \mathrm{p}=0.02$.

Thus, all three correlations were statistically significant. The strongest was the correlation between the number of brood cells and annual honey producion; $\mathrm{r}=0.96$.

Benefit cost analysis of honey production

Table 4 shows that the lowest amount of honey was produced by colonies of 5 CIS without a super, and the highest by colonies 
Table 3 .

Yield of honey $(\mathrm{kg})$ in colonies of different initial strengths supered in three methods, during a three year period. Each mean is calculated from 18 records ( 6 colonies x 3 years).

Each overall mean takes into account 54 records ( 6 colonies x 3 years x 3 seasons)

\begin{tabular}{|c|c|c|c|c|c|}
\hline $\begin{array}{l}\text { Colony } \\
\text { strength }\end{array}$ & Season & $\begin{array}{l}\text { Without super } \\
\text { Mean } \pm \text { se }\end{array}$ & $\begin{array}{l}\text { Shallow super } \\
\text { Mean } \pm \text { se }\end{array}$ & $\begin{array}{l}\text { Deep super } \\
\text { Mean } \pm \text { se }\end{array}$ & $\begin{array}{c}\text { Seasonal } \\
\text { mean }\end{array}$ \\
\hline \multirow{5}{*}{5 combs } & Autumn & $4.3 \pm 1.4 h^{*}$ & - & - & $4.3 C \&$ \\
\hline & Winter & $11.8 \pm 1.4 \mathrm{fg}$ & - & - & $11.8 \mathrm{~B}$ \\
\hline & Spring & $14.0 \pm 1.4$ def & - & & $14.0 \mathrm{~A}$ \\
\hline & Overall seasonal mean & $10.0 \pm 0.8 \mathrm{~d}^{\star \star}$ & - & - & 10.0 \\
\hline & \begin{tabular}{|l|} 
Total annual mean \\
\end{tabular} & $301 \pm 0.9 \mathrm{D} \#$ & - & - & 301 \\
\hline \multirow{5}{*}{10 combs } & Autumn & $6.5 \pm 1.4 \mathrm{~h}$ & $9.9 \pm 1.4 \mathrm{~g}$ & $14.3 \pm 1.4$ def & $10.2 \mathrm{~B}$ \\
\hline & Winter & $13.5 \pm 1.4 \mathrm{ef}$ & $19.3 \pm 1.4 c$ & $23.7 \pm 1.4 b$ & $18.9 \mathrm{~A}$ \\
\hline & Spring & $14.1 \pm 1.4$ def & $18.3 \pm 1.4 \mathrm{c}$ & $23.7 \pm 1.4 b$ & $18.7 \mathrm{~A}$ \\
\hline & Overall seasonal mean & $11.4 \pm 0.8 \mathrm{~d}$ & $15.8 \pm 0.8 \mathrm{c}$ & $20.6 \pm 0.8 b$ & 15.9 \\
\hline & Total annual mean & $34.1 \pm 16 \mathrm{D}$ & $47.5 \pm 2.1 \mathrm{C}$ & $62.2 \pm 2.1 \mathrm{~B}$ & 47.8 \\
\hline \multirow{7}{*}{20 combs } & Autumn & - & $15.9 \pm 1.4$ cde & $17.4 \pm 1.4 \mathrm{~cd}$ & $16.7 \mathrm{C}$ \\
\hline & Winter & - & $29.9 \pm 1.4 a$ & $30.6 \pm 1.4 \mathrm{a}$ & $30.2 \mathrm{~A}$ \\
\hline & Spring & - & $23.0 \pm 1.4 b$ & $26.5 \pm 1.4 \mathrm{~b}$ & $24.7 B$ \\
\hline & Overall seasonal mean & & $22.9 \pm 0.8 a$ & $24.8 \pm 0.8 a$ & 23.9 \\
\hline & Total annual mean & - & $68.2 \pm 31 \mathrm{AB}$ & $74.5 \pm 3.3 \mathrm{~A}$ & 71.6 \\
\hline & \multirow{2}{*}{$\begin{array}{l}\text { Overall seasonal mean } \\
\text { for all treatments }\end{array}$} & Autumn & Winter & Spring & \\
\hline & & $11.8 \pm 0.6 \beta$ & $19.9 \pm 0.6 \alpha$ & $21.5 \pm 0.6 \alpha$ & \\
\hline
\end{tabular}

* Different small letters after the means indicate significant difference $(\mathrm{P}<0.05)$ between them;

** Different small bold letters indicate 6 overall seasonal means, in 3 lines;

\# Different Capital Bold letters indicate 6 overall annual means, in 3 lines;

\& Different Capital regular-print letters indicate only 3 seasonal means of same-strength colonies;

(a) Different Greek letters indicate overall seasonal means for all treatments, last line.

Table 4.

Analysis of cost benefits for honey production by colonies in 6 groups

of different initial strength (CIS), supered by three methods in Terai region of Nepal (2003-2006)

\begin{tabular}{||l|c|c|c|c|c||}
\hline $\begin{array}{l}\text { Colony initial strength } \\
\text { (CIS)/supering methods }\end{array}$ & $\begin{array}{c}\text { Annual honey } \\
\text { production } \\
(\mathrm{kg}) \text { per colony }\end{array}$ & $\begin{array}{c}\text { Income from } \\
\text { honey NRs } \\
100 \text { per kg } \\
(\mathrm{a})\end{array}$ & $\begin{array}{c}\text { Cost of honey } \\
\text { production } \\
(\mathrm{b})\end{array}$ & $\begin{array}{c}\text { Net profit } \\
(\mathrm{a}-\mathrm{b})\end{array}$ & $\begin{array}{c}\text { Benefit } \\
(\mathrm{cost} \text { ratio } \\
\mathrm{a}: \mathrm{b})\end{array}$ \\
\hline $5 \mathrm{CIS}$ without super & 30.1 & 3010.0 & 2760.0 & 250.0 & $1.09: 1$ \\
\hline $10 \mathrm{CIS}$ without super & 34.1 & 3410.0 & 3668.5 & -258.5 & $0.93: 1$ \\
\hline $10 \mathrm{CIS}$ with a shallow super & 47.5 & 4750.0 & 4059.5 & 690.5 & $1.17: 1$ \\
\hline $10 \mathrm{ClS}$ with a deep super & 62.2 & 6220.0 & 4082.5 & 2137.5 & $1.52: 1$ \\
\hline 20 CIS with a shallow super & 68.8 & 6880.0 & 6727.5 & 152.50 & $1.02: 1$ \\
\hline 20 CIS with a deep super & 74.5 & 7450.0 & 6750.5 & 699.5 & $1.10: 1$ \\
\hline
\end{tabular}

100 Nepalese Rupees (NRs) $=1.17$ US dollar.

of 20 CIS with a deep supper. There was a similar relationship between the financial income from honey production and the cost of honey production.

However, the net profit differed. The colonies of 10 CIS without a super produced relatively low amounts of honey $(34.1 \mathrm{~kg})$.
The cost of production was higher than the financial income from honey (3410.0 NRs). The imbalance meant that the financial benefit was below $1(0.93: 1)$. The highest net profit (2137.5 NRs) was generated by the colonies of 10 CIS with a deep super. 
After the relationship between the net profit and the cost of production was calculated, it was revealed that the highest benefit was generated also by the colonies of 10 CIS with a deep super $(1.52: 1)$ followed by colonies of 10 CIS with shallow supers $(1.17: 1)$. Although the colonies of 20 CIS produced the highest amount of honey, the increased cost of production necessitated the reversal of the two bottom brood chambers, resulted in lower benefits $(1.10: 1$ or $1.02: 1)$.

Thus, the management of colonies of 10 CIS with a deep super, which generates the highest benefit, is recommended for beekeepers in the Terai region and mid hills of Nepal. This result has also global applications.

\section{DISCUSSION}

The main question of our investigation was to find out how the initial strength of A. mellifera colonies and the method of their supering, affects the amount of brood, number of foragers, and honey production in Nepal. Next, we calculated which of the two combinations resulted in the best financial benefit for the beekeepers.

We found that the annual honey yield from colonies of the three strength of 5,10 , and 20 CIS (strength ratio $1: 2: 4$ ) was at a rate of $1.0: 1.6: 2.4$, respectively, in comparison to the $30.1 \mathrm{~kg}$ produced by colonies of 5 CIS. As far as strength was concerned, the strongest colonies of 20 CIS produced proportionally the lowest amount of honey.

Farrar (1937) found that colonies with $15,000,30,000,45,000$ and 60,000 worker bees (ratio $=1: 2: 3: 4$ ) produced honey at a rate of $1.00,1.36,1.46$, and 1.54, respectively. Kumar et al. (1995) reported that in India, colonies covering $4,6,8$, and 10 combs produced $9-12$, and $18 \mathrm{~kg}$ of honey, respectively. According to Bhusal and Thapa (2006), and Bhusal et al. (2011) colonies of 4, 6, 8, and 10 CIS investigated in Nepal, produced honey at a rate of $1.00,1.18,1.54$ and 2.21, respectively, over a three month period, compared to $2.82 \mathrm{~kg}$ produced by the colonies of 4 CIS. This information shows that our results are compatible with the results of other authors.

According to Woyke (1984), the correlation between colony initial strength and the production of honey varied from $\mathrm{r}=0.38$ to 0.70 . Szabo and Lefkovitch (1989) reported that the correlation between the worker population and honey production was; $r=0.62$, and according to Genc and Aksoy (1993), it was $r=0.66$.

We also investigated the relationship between the number of brood cells and honey production. We found that the correlation between the seasonal mean number of brood cells, and the seasonal kilograms of honey produced by the six groups of colonies supered differently was; $\mathrm{r}=0.58, \mathrm{df}=17, \mathrm{p}=0.012$. The correlation between the annual amount of brood and the annual kilograms of honey produced by the colonies of the six treatment groups was higher; $r=0.96$, df $=5, p=0.003$. For the beekeeper, the annual production is important. The correlation concerning the annual results is very high and the probability is highly significant.

Our results are within those reported by Woyke (1981b) for different places and seasons in El Salvador ( $r=-0.09$ to 0.78$)$, and within those reported by Woyke (1984) for different months in Poland $(\mathrm{r}=0.20$ to $0.85)$. They are also within those reported by Szabo (1982) for different apiaries and months in Canada ( $\mathrm{r}=0.13$ to 0.89 ), and within those presented by Szabo and Lefkovitch (1989) for two dates during two years in Canada ( $\mathrm{r}=0.15$ to 0.65 ).

As far as the effect of the six treatments goes, we found that in comparison to the results of colonies of 5 CIS without a super, the bees of the two other groups of 10 CIS and 20 CIS (strength ratio $1: 2: 4$ ) produced:

1./ a number of brood cells at a rate of 1 : $(1.2: 1.4: 1.5):(1.8: 1.8)$,

2./ a number of out flying foragers at a rate of $1:(1.5: 1.6: 1.9):(2.8: 2.9)$,

$3 . /$ an annual $\mathrm{kg}$ of honey yield at a rate of $1:(1.1: 1.6: 2.1):(2.3: 2.5)$. 
It is visible that the rates differ for the three characters.

Our investigation was conducted over a time span of three years on a total of 108 colonies. Thus, the above results are credible. We found, that instead of annually producing $30 \mathrm{~kg}$ of honey by colonies of 5 CIS, it is possible to produce $74.5 \mathrm{~kg}$ of honey by colonies of 20 CIS in two brood chambers with a deep super. Annual production of honey by this method is three times higher than the present average honey production of $25 \mathrm{~kg}$ in Nepal. However, management method of colonies of 20 CIS is difficult. The two bottom brood chambers must be replaced up and down every two weeks. This requires much time and labor, which make it costly.

For the beekeepers, not only the height of the honey yield per bee colony is important but which management method generates the highest financial benefit. We found that the relationship between the income from the honey yield and the cost of production was the highest $(1.52: 1)$ for colonies of 10 CIS with a deep super, which produced $62.2 \mathrm{~kg}$ of honey annually (Tab. 4).

Thus, the management of colonies of 10 CIS with a deep super is recommended for the beekeepers in the Terai and lower hills regions of Nepal, for maximizing the benefit of honey production. Although the exact economic calculations are valid for lower Nepal, the general aspect of the economic evaluation has global application.

\section{CONCLUSIONS}

1. Initial colony strength of honey bees has been found to be one of the most important influencing factors for maximizing honey production by A. mellifera bees in Nepal.

2. Production of honey was significantly the lowest with a lower cost-benefit ratio in colonies of 5 comb initial strength which is practiced by farmers in Nepal.

3. The highest mean annual honey yield was produced by $A$. mellifera colonies of $20 \mathrm{comb}$ initial strength of bees in double brood chambers with a deep super. However, the benefit, the income from the honey / cost ratio was lower than in colonies of 10 CIS.

4. The colonies of 10 comb initial strength of bees with a deep super were the most superior supering method for obtaining a maximum profit of honey production by $A$. mellifera bees in the Terai region and mid hills of Nepal. The general aspect of the economic evaluation of different colony management has a global application.

\section{REFERENCES}

Bhusal S. J., Thapa R. B. (2006) - Response of colony strength to honey production: regression and correlation analysis. J. Inst. Agric. Anim. Sci., 27: 133-137. [on line] http:// jerzy_Woyke.users.sggw.pl/2006_Bhusal_ colony_strengh_honey.pdf

Bhusal S. J., Kafle L., Thapa R. B., Shih Ch. J. (2011) - Effect of colony strength on the performance of honeybees (Apis mellifera) in Nepal (Hymenoptera: Apidae). Sociobiology, 58(2): 435-447.

Farrar C. L. (1937) - The influence of colony populations on honey production. J. Agric. Res., 54(12): 945-954.

Genc F., Aksoy A. (1993) - Some of the correlations between the colony development and honey production of the honeybee (Apis mellifera L.) colonies. Apiacta, 28: 33-34.

Harbo J. R. (1986) - Effect of population size on brood production, worker survival and honey gain in colonies of honey bees. J. Apic. Res., 25: 22-29.

Kafle G. (1992) - Silent features of beekeeping in Nepal, in: Verma L. R. (ed.) Honey bees in mountain agriculture. Oxford and IBH Pub. Co. Pvt. Ltd., pp. 155-162.

Kumar J., Srivastava S., Kashyap N. P. (1995) - Effect of strength of worker bees on honey production in Apis mellifera colonies. Indian Bee J., 57(4): 174-176.

Pratap U. (1997) - Bee flora of the Hindu Kush Himalayas. Inventory and Management. ICIMOD, Kathmandu, Nepal, pp. 1 - 279. 
Shrestha J. B., Shrestha K. K. (2000) Beekeeping in Nepal. Problems and potentials. In Asian bees and beekeeping, Progress of research and development. Proceeding of fourth Asian Apiculture Association International Conference, Nepal - Kathmandu, March 23-28, 1998, pp. 262 - 265.

Szabo T. (1982) - Phenotypic correlations between colony traits in honey bee. Am. Bee J., 122: 711-716.

Szabo T. I., Lefkovitch L. P. (1989) - Effect of brood production and population size on honey production of honeybee colonies in Alberta, Canada. Apidologie, 20: 157-163.
Woyke J. (1981a) - Tablas pora determinar las cantidades de las crias en las colonias de abejas. Dir. Gener. Ganad., FAO., San Salvador: 1-9. [on line] http://jerzy_Woyke.users.sggw. pl/1981_tablas_cria.pdf

Woyke J. (1981b) - Influence of colony internal factors on honey production in El Salvador. In Proceedings of 28 Apimondia Congress, Mexico - Acapulco, 23-29 October, 1981. pp. 298-304.

Woyke J. (1984) - Correlations and interactions between population, length of worker life and honey production by honeybees in temperate region. J. Apic. Res., 23(3): 148-154.

\title{
WPLYW POCZĄTKOWEJ SILY RODZIN PSZCZELICH (A. mellifera) I METOD DODAWANIA NADSTAWEK NA ZWIĘKSZENIE PRODUKCJI MIODU W NEPALU
}

\author{
Neupane K., Woyke J., Wilde J. \\ S t r e s z c z e n i e
}

Oryginalną pszczołą utrzymywaną w Nepalu w ulach jest pszczoła wschodnia Apis cerana. Niedawno wprowadzono do Nepalu, egzotyczną dla tego kraju pszczołę Apis mellifera. Pszczoła ta produkuje więcej miodu niż pszczoła wschodnia. Jednakowoż właściwą gospodarkę pasieczną dla tej pszczoły w Nepalu trzeba dopiero opracować. Dlatego przeprowadzono badania mające wskazać, jaka metoda gospodarki zapewnia maksymalne korzyści dla pszczelarzy. W ciągu trzech lat badano jak początkowa siła rodziny oraz sposób dodawania nadstawek wpływa na cechy biologiczne i produkcję miodu. Badano również korzyści finansowe.

Rodziny okrywające początkowo 5, 10 lub 20 plastrów (Pl) albo nie otrzymywały nadstawki albo dodawano im pół nadstawkę lub całą nadstawkę z plastrami.

Stwierdziliśmy, że rodziny o początkowej sile 5, 10 lub $20 \mathrm{Pl}$ posiadały w ciagu sezonu średnio odpowiednio 10,9, 14,9 i 19,4 tysięcy komórek czerwiu (Tab. 1).

Średnia liczba zbieraczek wylatujących w ciągu 5 min z ula rodzin o początkowej sile 5,10 i $20 \mathrm{Pl}$ wynosiła odpowiednio 207, 349, 591 (Tab. 2).

Najsłabsze rodziny o początkowej sile $5 \mathrm{Pl}$ bez nadstawki wyprodukowały średnio $30,1 \mathrm{~kg}$ miodu. Rodziny średniej siły okrywające początkowo $10 \mathrm{Pl}$ bez nadstawki, z półnadstawką i pełną nadstawką wyprodukowały średnio odpowiednio 34,1, 47,5 i 62,2 kg miodu. Natomiast najsilniejsze rodziny o początkowej sile $20 \mathrm{Pl}$ z półnadstawką i pełną nadstawką wyprodukowały odpowiednio 68,2 i 74,5 kg miodu (Tab. 3). Tak więc najsilniejsze rodziny okrywające początkowo $20 \mathrm{Pl}$ z pełną nadstawką wyprodukowały 2,5 raza więcej miodu niż rodziny o początkowej sile 5 Pl bez nadstawki. Jednak, gdy obliczono stosunek dochodu do kosztów produkcji, to okazało sie, że był on najkorzystniejszy $(1,52: 1)$ dla miodu wyprodukowanego przez rodziny o początkowej sile $10 \mathrm{Pl}$ z pełną nadstawką (Tab. 4). Tak więc gospodarka pasieczna z pszczołą miodną A. mellifera, z rodzinami o początkowej sile $10 \mathrm{Pl} \mathrm{z}$ pełną nadstawką jest zalecana dla pszczelarzy w południowym Nepalu. Ekonomiczny aspekt oceny powyższych metod gospodarki pasiecznej ma również globalne znaczenie.

Słowa kluczowe: początkowa siła rodzin pszczelich, nadstawki, produkcja miodu, Nepal. 